\title{
Supplementation of Pandanus conoideus Oil in Cryopreservation Diluents for Maintaining the Semen Quality of Ongole Grade Bull
}

\author{
Nurcholis $^{a, *}$, A. Furqon ${ }^{b}$, R. I. Arifiantini ${ }^{c}$, \& S. M. Salamony ${ }^{a}$ \\ aDepartment of Animal Husbandry, Faculty of Agriculture, Musamus University, \\ Jalan Kamizaun Mopah Lama, Merauke, Papua 99611, Indonesia \\ bDepartment of Animal Science, Faculty of Animal Science, Brawijaya University, \\ Jalan Veteran, Malang, Jawa Timur 65145, Indonesia \\ 'Reproduction and Obstetrics Division, Department of Veterinary Clinic, Reproduction, and Pathology, \\ Faculty of Veterinary Medicine, IPB University, \\ Jalan Agatis Raya Kampus IPB Dramaga, Bogor, Jawa Barat 16680, Indonesia \\ *Corresponding author: nurcholis@unmus.ac.id \\ (Received 03-08-2020; Revised 22-10-2020; Accepted 02-11-2020)
}

\begin{abstract}
Antioxidants such as tocopherol, B-carotene, and polyunsaturated fatty acids (PUFA) from red fruit oil of Papua may be used to protect frozen semen. The study is aimed to test the effect of red fruit oil supplementation on motility, viability, and recovery rate of frozen sperm of Ongole-grade bulls. Semen was collected twice a month from eight 4-5-year-old male Ongole grade using an artificial vagina, followed by macro- and microscopical evaluations. Collected semen was divided into four tubes and diluted with tris egg yolk diluents (TEY) as a control, TEY supplemented with $0.5 \%$ red fruit oil (RFO) $\left(\right.$ TEY RFO R.5 $^{\text {) }}$, TEY supplemented with 1\% RFO (TEY RFO ${ }_{1.0}$ ), and TEY supplemented with 1.5\% RFO (TEY RFO ${ }_{1.5}$ ). The diluted semen was then packed into the straw and equilibrated for 2, 4, and $6 \mathrm{~h}$ prior to frozen on liquid nitrogen vapor for 10 minutes. The observed variables in this study were sperm motility, sperm viability, and morphology after equilibration, after thawing, and recovery rate. The experimental design is a completely randomized factorial design. The data were analyzed using ANOVA and were further tested using Duncan multiple range test. The results showed that the sperm motility of fresh semen was $81.10 \pm 1.42 \%$. The percentage of sperm motility in TEY RFO . $_{1.5}$ treatment at $6 \mathrm{~h}$ equilibration was $60.00 \pm 1.06 \%$, significantly higher compared to TEY $R F O_{1.0}$ and TEY RFO ${ }_{0.5}$. The percentage of postthawing sperm motility in TEY $\mathrm{RFO}_{1.5}$ treatment was $62.40 \pm 1.09 \%$. The best post-thawing sperm viability in TEY RFO ${ }_{1.5}$ was $80.70 \pm 1.20 \%$, significantly increase from the treatment of TEY RFO ${ }_{1.0}$ and TEY RFO T. $^{\circ}$ The recovery rate (RR) for TEY $\mathrm{RFO}_{1.5}$ treatment had the best percentage at $76.94 \%$. In conclusion, RFO supplementation in semen diluents for $2 \mathrm{~h}$ of equilibration resulted in the best motility and viability at 0 $h$ of post thawing observation.
\end{abstract}

Keywords: RFO supplementation; Ongole grade cattle; cryopreservation

\section{INTRODUCTION}

Reproductive technology, such as artificial insemination (AI) is widely used to increase cattle populations in Merauke-Papua (Nurcholis et al., 2019). Ongole grade cattle are preferred because they are tolerant to the local climate in Merauke. The frozen semen used for AI was produced by Singosari National Artificial Insemination Center. The proper handling of frozen semen is important to avoid sperm damage. The damage that occurred during freezing can be influenced by several factors, including the diluent factor, the semen freezing process, and storage (Nurcholis et al., 2016). Diluents containing cryoprotectants such as tris-aminomethane play an essential role in maintaining the quality of semen in the freezing process (Suyadi et al., 2012).

One of the factors causing the damage of semen in the freezing process is oxidative stress. The oxidative stress caused by cold shock and lipid peroxidation in the cell membrane leads to the decreased quality of the sperm. The plasma membrane of sperm of ruminant consists of polyunsaturated fatty acids (PUFA) which are susceptible to lipid peroxidation (Nurcholis et al., 2016). Lipid peroxidation in sperm changes the structure of its cell membrane. Change in the membrane structure will interfere with the stability and function of the membrane. In addition, oxidative stress (OS) and lipid peroxidation (LP) lead to mitochondrial damage, impaired adenosine triphosphate (ATP) production, and therefore decrease sperm motility (Wagner et al., 2017).

Antioxidants are often used as diluents supplementation to reduce lipid peroxidation in the sperm during freezing. Eriani et al. (2018) reported the use of $\beta$-carotene supplementation in freezing semen of buffalo. In addition, tocopherol supplementation had a beneficial effect on sperm motility on Maduran bulls (Ratnani et al., 2017). Other studies report that the natural antioxidants are being used in semen freezing, such as Nigella Sativa oil (Maidin et al., 2018), Moringaceae extract (Syarifuddin et al., 2017), and curcumin in cryopreservation of bovine semen (Bucak et al., 2012). Natural antioxidants supplementation in diluent is 
believed to counteract free radicals and maintain sperm quality.

Red fruit oil (RFO) has high antioxidants contents, including $\beta$ carotene, $\alpha$ tocopherol (Sarungallo et al., 2015), and PUFAs such as oleate and linoleate. PUFA can maintain cell membrane permeability (Byrne et al., 2017). Unfortunately, the studies of RFO supplementation in semen diluents are limited. Considering the high potential of antioxidant and PUFA content in RFO to prevent negative effects of oxidative stress, the study is aimed to test the effect of red fruit oil supplementation on motility, viability, and recovery rate of frozen sperm of Ongole grade bulls.

\section{MATERIALS AND METHODS}

\section{Research Locations and Animals}

The study was carried out at the Livestock Group Unit and the Semangga Sub-District Animal Health Laboratory Unit. A total of four Ongole grade bulls aged 4-5 years with high libido were used in this study. The bulls were individually penned and fed with normal quality feed ( $10 \%$ of body weight). The feed contained $60 \%$ forage and $40 \%$ silage. The bulls had free access to water (ad-libitum). All experiments involving animals were approved by The Animal Ethic Committee of Musamus University Number 13/UN.52.8/KL/2021 of 2021.

\section{Semen Collection and Evaluation}

Semen was collected in the morning at 06.30-07.30 am using an artificial vagina and an estrus cow as a live teaser. The ejaculate from each bull was collected twice a week for one month. The collected semen was immediately evaluated both macroscopically and microscopically after collection. Macroscopic observations included volume, $\mathrm{pH}$, consistency, and color. Evaluations of semen volume, consistency, and color were determined visually. The observation of $\mathrm{pH}$ was measured using a paper indicator (Merck, scale 6.4-8). Microscopic evaluation in this study included mass movement, sperm motility, sperm viability, concentration, and morphology (normal and abnormal).

In the determination of sperm motility, a drop of semen was diluted 5 times in $0.9 \% \mathrm{NaCl}$ and homogenized on the object-glass. One drop of the mixture was transferred to a new object-glass and covered with a glass cover. The observation was performed under the light microscope with 400 times magnification at five different fields of view. The assessment of sperm motility was determined in the range of $0-100 \%$.

The viability (live sperm) was analyzed using Eosin-Nigrosin (EN) staining. For this protocol, one drop of semen and 4-5 drops of EN (60-75 $\mu \mathrm{L})$ were used in this mixture. The prepared slide was dried on the heating table. The slides were observed under a microscope at 10 fields of view with a minimum number of cells counted 200. Viable or live sperm did not absorb the stain, and the heads were clear, whereas the nonviable/dead sperm absorbed the stain, so the head was red. Morphological observations of sperm consisted of normal and abnormal sperm. Sample preparation was performed as previously described in the viability test. Observation under a light microscope with magnification 400 times was made on 200 sperm. Percent of normal sperm were determined by the number of normal sperm divided by the total number of sperm (normal and abnormal) and multiplied by $100 \%$. All microscopic observations of sperm quality were performed using a binocular microscope (Olympus CX43, Japan).

The concentration of sperm was calculated by counting sperm at 5 large squares in the Neubauer Chamber slide (4 chamber corners and 1 chamber in the middle). The head of sperm contained in the box is counted 1, while the head of sperm that are in the boundary line is rated $1 / 2$. The sperm concentration was calculated by the number of sperm cells in 5 chambers $x$ $5 \times$ dilution factor $(1: 200) \times 10000$

\section{Diluents Preparation}

The buffer has been prepared, according to Arifiantini \& Yusuf (2010). The buffer consisted of 30.28 $\mathrm{g}$ of Tris-hydroxymethyl-aminomethane, $17.8 \mathrm{~g}$ of citric acid, and $12.5 \mathrm{~g}$ of D-fructose in $100 \mathrm{~mL}$. The sperm diluent was consisted of 74\% Tris Buffer (v/v), 20\% egg yolk (v/v), Glycerol 6\% (v/v), Penicillin (IU) 100,000 $\mathrm{mg}$, and Streptomycin $100 \mathrm{mg}$. The treatment levels of supplemented diluents of red fruit oil (RFO) were Tris Egg yolk diluents (TEY) as a control (P0), P1 was TEY supplemented with red fruit oil (RFO) 0.5\% (v/v) (TEY $\left.\mathrm{RFO}_{0.5}\right)$, P2 was TEY supplemented with RFO 1\% (v/v) (TEY RFO ${ }_{10}$ ), and P3 was TEY supplemented with RFO $1.5 \%(\mathrm{v} / \mathrm{v})\left(\mathrm{TEY} \mathrm{RFO}_{1.5}\right)$. (The process of preparing RFO cannot be presented in a script because it is in the process of Patent application).

\section{Semen Processing}

The fresh semen of Ongole Grade bulls with motility percentage above $70 \%$, concentrations above $700 \mathrm{x}$ $10^{6}$ sperm per $\mathrm{mL}$, and abnormalities less than $5 \%$ was used in the experiment. The semen mixing process was carried out with a ratio of diluent: semen was 9:1. The mixture was homogenized and put into the 0.25 $\mathrm{mL}$ mini straw. Each treatment had five replicates $(\mathrm{n}=$ $5)$. In equilibration, the semen straws were kept in the refrigerator $\left(5^{\circ} \mathrm{C}\right)$ for 2,4 , and 6 hours. The method of equilibration in the refrigerator $\left(5^{\circ} \mathrm{C}\right)$ was already used in previous studies (Soltan et al., 2016; Elhammali et al., 2019). The durations of equilibration were 4 and 6 hours at $4^{\circ} \mathrm{C}$, according to Fleisch et al. (2017) and Murphy et al. (2017), respectively. Furthermore, the equilibrated semen was transferred into a Styrofoam box containing liquid nitrogen with a depth of about $10 \mathrm{~cm}$ above the surface of liquid nitrogen for 10 minutes, and then the semen was ready to be frozen into liquid nitrogen at $-196^{\circ} \mathrm{C}$. The post-thawing evaluation was done by placing the straw into the warm water at $37^{\circ} \mathrm{C}$ for 30 seconds with an observation time of 0 hours, 0.5 hours, and 1 hour. During the observation, the semen straws were kept in a water bath $\left(37^{\circ} \mathrm{C}\right)$. The post-thawing evaluation 
included motility, viability, and recovery rate (RR). The recovery rate was calculated by comparing the percentage of motile sperm in post thawing and fresh semen and multiplied by $100 \%$.

\section{Statistical Analysis}

All data were presented as mean value \pm SEM. The evaluation values of equilibration and post-thawing were analyzed using two-way ANOVA. Some factors, including RFO concentration, equilibration time, and warming time, were used in this study. The experimental design is a completely randomized factorial design. The effect of interaction between two factors on sperm quality was analyzed during post equilibration and post thawing. Data were further tested using Duncan multiple range test in SPSS ver. 21.0 software with significant differences alpha $0.05(\mathrm{p}<0.05)$.

\section{RESULTS}

\section{Characteristics of Fresh Semen of Ongole Grade Bull}

Characteristics of fresh semen in Ongole Grade bulls are presented in Table 1 . The averages of semen quality and quantity observed in this study were under normal conditions.

Table 1. Characteristics of fresh semen of Ongole Grade bulls $(n=4)$

\begin{tabular}{lc}
\hline \multicolumn{1}{c}{ Variables } & Mean \pm SEM \\
\hline Macroscopic & \\
Volume $(\mathrm{mL})$ & $4.8 \pm 0.10$ \\
Consistency & Moderate to thick \\
$\mathrm{pH}$ & $6.30 \pm 0.00$ \\
Color & Cream \\
Microscopic & \\
Mass activity & ++ \\
Sperm motility $(\%)$ & $81.10 \pm 1.42$ \\
Sperm viability $(\%)$ & $86.25 \pm 1.60$ \\
Sperm abnormality $(\%)$ & $3.2 \pm 0.30$ \\
Sperm concentration $\left(\mathrm{x} 10^{6} / \mathrm{mL}\right)$ & $1020 \pm 72.50$ \\
\hline
\end{tabular}

Note: The collection of semen eight times in four bulls.

\section{The Quality of Semen Post Equilibration}

In this experiment, no effect between the level of diluent and equilibration time was found on the post equilibration semen quality. The $1.5 \%$ RFO supplementation (P3 treatment) in the diluent at $6 \mathrm{~h}$ equilibration resulted in a higher motility rate compared to the other treatments $(p<0.05)$. However, the difference in the percentage of motility between P3 and P2 was not significant. In addition, no significant difference in the percentages of motility among $\mathrm{P} 2, \mathrm{P} 0$, and $\mathrm{P} 1$ was observed after 6 hours of equilibration (Table 2). The percentage of viability of sperm was found to be the highest $(\mathrm{p}<0.05)$ in P3 diluent compared to P2, P1, and P0 (control) diluents 6 hours after equilibration. Sperm's viability in P2 diluent was higher $(\mathrm{p}<0.05)$ than in P1 and P0 diluents. However, the viabilities of sperm between P1 and P0 diluents did not differ significantly after 6 hours of semen equilibration (Table 2). The best interaction between time of equilibration and RFO concentration was at 2 hours treatment and 1.5\% RFO supplementation.

\section{The Quality of Semen Post Thawing}

There was no interaction effect between the level of diluents and time post thawing on semen quality. The percentage of sperm motility in P3 diluent was found significantly $(\mathrm{p}<0.05)$ higher at 0 to 1.5 hours of storage compared with motilities in P1, P2, and P0 diluents. There was no difference in sperm motilities among P2, P1, and P0 diluents. The percentage of sperm motility in the four treatments decreased with the increased storage time and up to 1.0 hour of storage. The motility of sperm was maintained $\geq 40 \%$, except for P0 diluent. After 1.5 hours of storage, the motility of sperm in all diluents dropped sharply below 40 percent (Table 3). The percentage of sperm viability was found to be the highest $(\mathrm{p}<0.05)$ in $\mathrm{P} 3$ diluent compared to that of $\mathrm{P} 2, \mathrm{P} 1$, and P0 (control) diluents in all post-thawing time. The differences in observation time showed that the influence of $\mathrm{RFO}_{1.0^{-} .5}$ had a significant effect $(\mathrm{p}<0.05)$ on sperm viability. The best sperm viability was observed $0 \mathrm{~h}$ or shortly after the thawing process at $37^{\circ} \mathrm{C}$ for 30 seconds that was significantly higher $(\mathrm{p}<0.05)$ compared to the observations $0.5 \mathrm{~h}, 1 \mathrm{~h}$, and $1.5 \mathrm{~h}$ after thawing process.

Table 2. Sperm motility and sperm viability of post equilibration at $5^{\circ} \mathrm{C}$ supplemented with red fruit oil (RFO) in diluent ( $\left.\mathrm{n}=20\right)$

\begin{tabular}{|c|c|c|c|c|}
\hline \multirow{2}{*}{ Variables } & \multirow{2}{*}{ Diluent } & \multicolumn{3}{|c|}{ Post equilibration (h) } \\
\hline & & 2 & 4 & 6 \\
\hline \multirow[t]{4}{*}{ Motility (\%) } & P0 (TEY-Control) & $65.45 \pm 1.04^{\mathrm{a}}$ & $55.14 \pm 1.04^{\mathrm{a}}$ & $50.84 \pm 1.10^{\mathrm{a}}$ \\
\hline & P1 (TEYRFO ${ }_{0.5}$ ) & $66.00 \pm 1.12^{\mathrm{a}}$ & $56.00 \pm 1.11^{\mathrm{a}}$ & $52.10 \pm 1.14^{\mathrm{a}}$ \\
\hline & P2 $\left(\right.$ TEYRFO $\left.{ }_{1.0}\right)$ & $68.20 \pm 1.04^{\mathrm{abx}}$ & $62.40 \pm 1.17^{\text {aby }}$ & $58.23 \pm 1.00^{\mathrm{abz}}$ \\
\hline & P3 (TEYRFO $\left.{ }_{1.5}\right)$ & $72.15 \pm 1.07^{\mathrm{bx}}$ & $65.25 \pm 1.05^{\text {by }}$ & $60.00 \pm 1.06^{\mathrm{bz}}$ \\
\hline \multirow[t]{4}{*}{ Viability (\%) } & P0 (TEY-control) & $68.54 \pm 1.04^{\mathrm{a}}$ & $60.10 \pm 1.11^{\mathrm{a}}$ & $54.00 \pm 1.13^{\mathrm{a}}$ \\
\hline & P1 (TEYRFO 0.5$)$ & $72.00 \pm 1.11^{\mathrm{abx}}$ & $62.00 \pm 1.00^{\mathrm{bx}}$ & $60.20 \pm 1.03^{\text {ay }}$ \\
\hline & P2 $\left(\right.$ TEYRFO $\left._{1.0}\right)$ & $75.20 \pm 1.06^{\mathrm{bx}}$ & $68.20 \pm 1.10^{\text {by }}$ & $64.05 \pm 1.14^{\mathrm{bz}}$ \\
\hline & P3 (TEYRFO $\left.{ }_{1.5}\right)$ & $79.70 \pm 1.04^{c}$ & $73.70 \pm 1.05^{c}$ & $68.10 \pm 1.25^{c}$ \\
\hline
\end{tabular}

Note: $a, b, c=$ means in the same column with different superscripts differ significantly $(p<0.05) .{ }^{x, y, z}=$ means in the same row with different superscripts differ significantly $(\mathrm{p}<0.05)$. P0 (TEY-Control)= tris egg yolk diluents (TEY) as a control, P1 $\left(\right.$ TEYRFO $\left.{ }_{0.5}\right)=\mathrm{TEY}$ supplemented with red fruit oil (RFO) $0.5 \%(\mathrm{v} / \mathrm{v}), \mathrm{P} 2\left(\mathrm{TEYRFO}_{1.0}\right)=$ TEY supplemented with RFO 1\% (v/v), P3 $\left(\mathrm{TEYRFO}_{1.5}\right)=\mathrm{TEY}$ supplemented with RFO 1.5\% (v/v). 


\section{Recovery Rate (RR) of Sperm of Ongole Grade Bulls}

The percentage of recovery rate of sperm can be interpreted as the sperm ability to revive after cryopreservation. In this study, the highest $R R$ value $(p<0.05)$ was found in sperm diluted in P3 (TEY $+1.5 \%$ RFO) diluent in all observation times (Table 4 ). The recovery rates of sperm in all treatments with RFO were higher than in control (P0).

\section{DISCUSSION}

The quality of fresh semen collected from four Ongole Grade bulls aged 4-5 years was normal, i.e., the volume was $4.8 \mathrm{~mL}$. The semen volume found in the present experiment is lower than the volume reported by Nugraha et al. (2019) that the volume of bull semen correlates with age, i.e., at the age of 4 years, the volume of semen is $4.90 \mathrm{~mL}$ on average. This difference is caused by different types of cattle. The collected semen can be continued for the cryopreservation process because the fresh semen has motility above $70 \%$, viability above $80 \%$, and abnormalities below 5\%. According to Kaka et al. (2016), the progressive motility of sperm in fresh sperm is a viable indicator for the freezing process, and the percentage of motility was above $60 \%$ (MacKenna et al., 2017).

Before the freezing process, the semen should be equilibrated to adapt the sperm to the freezing conditions. Equilibration of sperm has been carried out with various times and temperatures, for example, with temperatures of $4^{\circ} \mathrm{C}$ for 6 hours (Herbowo et al., 2019) and $5^{\circ} \mathrm{C}$ for 22 hours (Dwinofanto et al., 2018). The metabo- lism of sperm can be suppressed if the semen is cooled at $0^{\circ} \mathrm{C}-5^{\circ} \mathrm{C}$. Stress conditions of sperm can interfere with the process of inhibition of phosphorylation and phospholipid oxidation, which results in the increased production of reactive oxygen species (ROS) in the semen, and excessive levels of ROS in the cells can increase the oxidation of lipids, proteins, and DNA.

The good motility of sperm equilibrated in P3 treatment $(\mathrm{p}<0.05)$ is thought to be due to the higher contents of oleic and linoleic acids, as well as antioxidants and phospholipids in the RFO compared to the other diluents. These compounds protect the plasma membrane and prevent lipid oxidation so that lipid peroxidation can be reduced. Esmaeili et al. (2012) reported that phospholipids could protect sperm during cooling or freezing. Other studies report that equilibration at $5^{\circ} \mathrm{C}$ using MDA diluents is able to suppress ROS (Amaliya et al., 2017) at the same temperature and the antioxidants in Nigella sativa Oil are able to maintain goat sperm cells (Maidin et al., 2018). In addition, the PUFA content of $\mathrm{RFO}$ is able to provide protection to maintain the integrity of sperm and mitochondrial cell membranes so that the mitochondria are able to produce energy from ATP. The results showed that P3 treatment with 2 hours of post equilibration time was the best time before the decrease in sperm motility and viability of sperm at 4 hours and 6 hours. The decreased sperm's motility and viability can occur during the equilibration process at a range of temperatures of $4^{\circ} \mathrm{C}-5^{\circ} \mathrm{C}$ for $0-120$ minutes (Doležalová et al., 2016).

During the equilibration process, the cold shock will result in changes in the structure and permeability of the cell membrane (Sieme et al., 2015). The function

Table 3. Sperm motility and sperm viability of post thawing supplemented with red fruit oil (RFO) in diluent $(n=20)$

\begin{tabular}{|c|c|c|c|c|c|}
\hline \multirow{2}{*}{ Variables } & \multirow{2}{*}{ Diluents } & \multicolumn{4}{|c|}{ Post thawing $(\mathrm{h})$} \\
\hline & & 0 & 0.5 & 1 & 1.5 \\
\hline \multirow[t]{4}{*}{ Motility (\%) } & P0 (TEY-Control) & $49.90 \pm 1.20^{\mathrm{a}}$ & $46.00 \pm 0.04^{\mathrm{a}}$ & $39.04 \pm 0.30^{\mathrm{a}}$ & $20.84 \pm 0.10^{\mathrm{a}}$ \\
\hline & P1 $\left(\right.$ TEYRFO $\left.{ }_{0.5}\right)$ & $50.00 \pm 0.35^{\mathrm{a}}$ & $46.20 \pm 0.10^{\mathrm{a}}$ & $40.00 \pm 0.10^{\mathrm{a}}$ & $22.10 \pm 0.15^{\mathrm{a}}$ \\
\hline & P2 $\left(\right.$ TEYRFO $\left.{ }_{1.0}\right)$ & $58.00 \pm 1.25^{\mathrm{abw}}$ & $54.70 \pm 1.34^{\mathrm{abx}}$ & $46.40 \pm 1.10^{\text {aby }}$ & $35.23 \pm 0.75^{\mathrm{abz}}$ \\
\hline & P3 $\left(\right.$ TEYRFO $\left.{ }_{1.5}\right)$ & $62.40 \pm 1.09^{\mathrm{bw}}$ & $59.00 \pm 1.20^{\mathrm{bx}}$ & $47.25 \pm 1.50^{\text {by }}$ & $37.00 \pm 1.50^{\mathrm{bz}}$ \\
\hline \multirow[t]{4}{*}{ Viability (\%) } & P0 (TEY-control) & $69.84 \pm 0.04^{\mathrm{a}}$ & $59.84 \pm 0.20^{\mathrm{a}}$ & $50.10 \pm 1.12^{\mathrm{a}}$ & $26.00 \pm 1.20^{\mathrm{a}}$ \\
\hline & P1 (TEYRFO 0.5$)$ & $71.00 \pm 0.10^{\mathrm{abw}}$ & $61.00 \pm 0.50^{\mathrm{abx}}$ & $54.00 \pm 0.70^{\text {by }}$ & $26.09 \pm 0.62^{\mathrm{az}}$ \\
\hline & P2 $($ TEYRFO & $75.20 \pm 0.34^{\mathrm{bw}}$ & $68.20 \pm 0.15^{\mathrm{bx}}$ & $65.20 \pm 0.20^{\text {cy }}$ & $40.15 \pm 0.14^{\mathrm{bz}}$ \\
\hline & P3 $\left(\right.$ TEYRFO $\left.{ }_{1.5}\right)$ & $80.70 \pm 1.20^{\mathrm{cw}}$ & $73.70 \pm 1.34^{\mathrm{cx}}$ & $69.70 \pm 1.15^{\mathrm{dy}}$ & $44.05 \pm 0.95^{\mathrm{cz}}$ \\
\hline
\end{tabular}

Note: $a, b, c=$ means in the same column with different superscripts differ significantly $(p<0.05)$; ${ }^{, x, y, z}=$ means in the same row with different superscripts differ significantly $(\mathrm{p}<0.05)$. P0 (TEY-Control)= tris egg yolk diluents (TEY) as a control, P1 (TEYRFO $\left.{ }_{05}\right)=$ TEY supplemented with red fruit oil (RFO) $0.5 \%(\mathrm{v} / \mathrm{v})$, P2 $\left(\right.$ TEYRFO $\left._{1.0}\right)=$ TEY supplemented with RFO 1\% (v/v), P3 $\left(\right.$ TEYRFO $\left._{1.5}\right)=\mathrm{TEY}$ supplemented with RFO $1.5 \%(\mathrm{v} / \mathrm{v})$.

Table 4. Recovery rate (RR) of sperm motility of Ongole Grade bulls post thawing

\begin{tabular}{ccccccc}
\hline \multirow{2}{*}{ Variables } & \multirow{2}{*}{ Fresh semen } & \multicolumn{5}{c}{ Recovery rate $(\%)$} \\
\cline { 3 - 7 } & & $0 \mathrm{~h}$ & $0.5 \mathrm{~h}$ & $1 \mathrm{~h}$ & $1.5 \mathrm{~h}$ & $2 \mathrm{~h}$ \\
\hline P0 & & $49.90 \pm 1.20^{\mathrm{a}}$ & $61.53 \pm 1.20^{\mathrm{a}}$ & $56.72 \pm 1.14^{\mathrm{a}}$ & $48.14 \pm 1.14^{\mathrm{a}}$ & $25.70 \pm 1.21^{\mathrm{a}}$ \\
P1 & \multirow{2}{*}{$1.10 \pm 1.42$} & $50.00 \pm 0.35^{\mathrm{a}}$ & $61.65 \pm 1.05^{\mathrm{a}}$ & $56.97 \pm 1.25^{\mathrm{a}}$ & $49.32 \pm 1.25^{\mathrm{a}}$ & $27.25 \pm 1.35^{\mathrm{a}}$ \\
P2 & & $58.00 \pm 1.25^{\mathrm{ab}}$ & $71.52 \pm 1.10^{\mathrm{abw}}$ & $67.45 \pm 1.30^{\mathrm{abx}}$ & $57.21 \pm 1.17^{\mathrm{aby}}$ & $3.44 \pm 1.40^{\mathrm{abz}}$ \\
P3 & & $62.40 \pm 1.09^{\mathrm{b}}$ & $76.94 \pm 1.25^{\mathrm{bw}}$ & $61.65 \pm 1.15^{\mathrm{bx}}$ & $58.26 \pm 1.06^{\text {by }}$ & $45.62 \pm 1.15^{\mathrm{bz}}$ \\
\hline
\end{tabular}

Note: $a, b, c=$ means in the same column with different superscripts differ significantly $(p<0.05)$; $w, x, y, z=$ means in the same row with different superscripts differ significantly $(\mathrm{p}<0.05) . \mathrm{P} 0=$ Control; $\mathrm{P} 1=\mathrm{TEY}+0.5 \mathrm{~g}$ red fruit oil $(\mathrm{RFO}) ; \mathrm{P} 2=\mathrm{TEY}+1 \mathrm{~g}$ RFO; $\mathrm{P} 3=\mathrm{TEY}+1.5 \mathrm{~g}$ RFO. 
of protein membrane will change due to cold shock by inducing the dysfunction of the ion channel causing impaired motility and viability. In addition, lipids can help to prevent cold shock by preventing moderate calcium ions and preventing them from entering sperm cells. According to Oldenhof et al. (2013), cell membrane damage will also occur during the cooling process, and this damage is caused by the changes in the structure of the bilayer membrane to be hexagonal and cold shock occurs at a temperature of $5^{\circ} \mathrm{C}-15^{\circ} \mathrm{C}$.

Cryopreservation may damage sperm. Supplementation of RFO in TEY diluents is important to prevent sperm damage and maintain the balance of osmotic pressure during freezing. Nurcholis et al. (2016) stated that the formation of ice crystals could damage the sperm membrane. Damage to the membrane in the midpiece can interfere with ATP formation by the mitochondria, thereby reducing the percentage of sperm motility. The higher the number of sperm that are damaged by freezing, the lower the number of sperm that can recover after freezing. In this study, the highest percentages of motility and viability of post thawing sperm of Ongole crossbred cattle diluted in TEY $\mathrm{RFO}_{1.5}$ indicate better protection when compared with the other treatment diluents. The differences $(p<0.05)$ in motility and viability of sperm among the four different diluents are influenced by different RFO levels. In addition, the lecithin compounds found in egg yolk play an active role with $\alpha$-tocopherol. Several supporting studies have developed lecithin in the size of nanoparticles mixed with $\alpha$-tocopherol (Mousavi et al., 2019). The mixture of $\alpha$-tocopherol in RFO with lecithin compounds in egg yolks can inhibit hydrogen peroxide $\left(\mathrm{H}_{2} \mathrm{O}_{2}\right)$ production that eventually protects the plasma membrane of the sperm from major damage. The use of a mixture of these two compounds was shown to be able to protect sperm from the toxic effects of $\mathrm{H}_{2} \mathrm{O}_{2}$ (Vieira et al., 2018). This statement is reinforced by Zhang et al. (2012), who report that the use of antioxidants in semen diluents could reduce the toxic effects on sperm during the cryopreservation process.

The protective abilities of lecithin, phospholipids, $\alpha$-tocopherol, and PUFA on TEY RFO diluents were seen in the plasma membrane in the head and tail of sperm. This protective effect was indicated by the high percentages of motility and viability. Egg yolk has properties contributed by lipoprotein and lecithin, which have the task of maintaining and protecting the integrity of the lipoprotein membrane covering the sperm cells of cattle. In addition, the yolk also contains glucose that has a better function to be used by sperm for metabolic processes compared to fructose contained in the semen. Membrane integrity and high viability can be seen from the post thawing test. Sperm, which do not absorb dyes, proved that the plasma membrane is still functioning correctly. In this study, sperm in the TEY $\mathrm{RFO}_{1.5}$ diluent at 0 hours could recover and reach RR as high as $76.94 \pm 1.25 \%$. This high RR was contributed by the role of compounds contained in TEY based-diluent and RFO as a supplement. The RR value in this study is higher than the results reported in cattle, i.e., $64.04 \%$ (Arifiantini \& Yusuf, 2010) and 60.2\% (Yendraliza et al.,
2019). The differences are thought to be due to diluent composition and the type of its ingredient supplementation. Ashmawy et al. (2010) reported that they found RR value only $65.9 \pm 0.25 \%$ by using egg yolk diluents.

Overall results of cryopreservation of Ongole crossbred semen in TEY diluent supplemented with RFO have a positive impact that can be used in the artificial insemination (AI) program. In SNI No. 4869.1: 2017, it is stated that for AI cattle, the frozen-thawed sperm must have at least $40 \%$ progressive motility.

\section{CONCLUSION}

The findings of this study suggest that $1.5 \%$ of RFO supplementation in semen diluents for $2 \mathrm{~h}$ of equilibration result in the best motility and viability at $0 \mathrm{~h}$ of post thawing observation. A similar effect of P3 treatment (TEY $\mathrm{RFO}_{1.5}$ ) was found in the recovery rate for $0.5 \mathrm{~h}$. According to the description, the inseminator had to consider AI preparation time because the post thawing semen quality would decrease with time. For the best result, the time needed by the inseminator on AI preparation is $0-0.5 \mathrm{~h}$.

\section{CONFLICT OF INTEREST}

The authors declare that there is no conflict of interest that could be perceived as prejudicing the impartiality of the research reported.

\section{ACKNOWLEDGEMENT}

This research is supported and funded by the Ministry of Research and Technology/BRIN of the Republic of Indonesia, which has provided our research assistance through the 2020 PDP Scheme Program, with a contract number 119.18/UN.52.8/LT/2020.

\section{REFERENCES}

Amaliya, A., S. Utama, \& Hardijanto. 2017. Quality, expression of HSP 70 and DNA damage on post-thawed Limousin bull after preservation at $5^{\circ} \mathrm{C}$. Veterina Medika. 10:77-86.

Arifiantini, R. I. \& T. L. Yusuf. 2010. Developing of tris soy milk diluent for frisian holstein bull frozen semen. Hayati Journal Biosci. 17:91-94. https://doi.org/10.4308/hjb.17.2.91

Ashmawy, T. A. M., A. A. Sallam, A. E. Abd El-Khalek, B. E. El-Saidy, \& M. G. Gabr. 2010. Recovery and fertilization rates of goat spermatozoaas affected by different levels of egg-yolk, dilution rates, freezing method and months of the year. J. Sheep Goat Sci. 5:283-293.

Byrne, C. J., D. A. Kenny, S. Fair, A. M. English, S. A. Holden, J. R. Dick, \& P. Lonergan. 2017. Dietary polyunsaturated fatty acid supplementation of young postpubertal dairy bulls alters the fatty acid composition of seminal plasma and spermatozoa but has no effect on semen volume or sperm quality. Theriogenology 90:28-300. https://doi. org/10.1016/j.theriogenology.2016.12.014.

Bucak, M.N., N. Baspinar, P. B. Tuncer, K. Coyan, S. Sarioskan, P. P. Akalin, S. Bu“ yu“ kleblebic, \& S. Kucukgu“nay. 2012. Effects of curcumin and dithioerythritol on frozenthawed bovine semen. Andrologia 44:102-109. https://doi. org/10.1111/j.1439-0272.2010.01146.x

Doležalová,M.,L.Stádník.,Z.Biniová.,J.Ducháček,\&R.Stupka. 2016. Equilibration and freezing interactions affecting bull 
sperm characteristics after thawing. Czech J. Anim. Sci. 61:515-525. https://doi.org/10.17221/23/2016-CJAS

Dwinofanto, H., Rimayanti , I. Mustofa, S. Susilawati , \& T. Hernawati. 2018. The effect of duration of preservation on the quality, MDA level, and DNA damage of post-thawed Bali cattle bull sperm. Iraqi J. Vet. Sci. 32:249-252. https:// doi.org/10.33899/ijvs.2019.153857

Elhammali, N. S., A. S. Elsheikh, \& S. E. A. Makawi. 2019. Fertility of friesian bull's semen diluted with low fat cow milk. IOSR J. Agric. Vet. Sci. 12:62-66. https://doi. org/10.9790/2380-1203016266

Eriani, K., A. Azhar, M. Ihdina, B. Rosadi, M. Rizal, \& A. Boediono. 2018. Quality enhancemen of Aceh swamp buffalo (Bubalus bubalis) frozen semen by supplementing $B_{-}-$ carotene. Trop. Anim. Sci. J. 41:1-7. https://doi.org/10.5398/ tasj.2018.41.1.1

Esmaeili, V., A. H. Shahve, A. R. Alizadeh, H. Alipour, \& M. Chehraz. 2012. Saturated, omega- 6 and omega-3 dietary fatty acid effects on the characteristics of fresh, frozenthawed semen and blood parameters in rams. Andrologia. 46:1-8. https://doi.org/10.1111/and.12040

Fleisch, A., E. Malama, U. Witschi, C. Leiding, M. Siuda, F. Janett, \& H. Bollwein. 2017. Effects of an extension of the equilibration period up to 96 hours on the characteristics of ryopreserved bull semen. Theriogenology 89:255-262. https://doi.org/10.1016/j.theriogenology.2016.10.018

Herbowo, M .T., R. I. Arifiantini, N. W. K. Karja, \& R. G. Sianturi. 2019. Cryopreservation of swamp buffalo semen in skim milk yolk-based diluent with two different cryoprotectants. Trop. Anim. Sci. J. 42:13-18. https://doi. org/10.5398/tasj.2019.42.1.13

Kaka, A., A. A. Memon, P. Khatri, H. K. Kumbhar, D. H. Kalhoro, M. Tariq, S. A. Pirzado, \& A. N. Tunio. 2016. Determination of quality characteristics of Khundi buffalo bull semen. J. Basic Appl. Sci. 12: 394-397. https://doi. org/10.6000/1927-5129.2016.12.61

Maidin, M.S., M. H. Padlan, S. A. N. Azuan, R. Jonit, N. H. Mohammed, \& R. Abdullah. 2018. Suplementation of Nigella sativa and honey prolong the survival rate of fresh and post-thawed goad sperms. Trop. Anim. Sci. J. 41:94-99. https://doi.org/10.5398/tasj.2018.41.2.94

MacKenna, A., J. Crosby, C. Huidobro, E. Correa2, \& G. Duque. 2017. Semen quality before Cryopreservation and after thawing in 543 patients with testicular cancer. JBRA Assist. Reprod. 21:31-34. https://doi. org/10.5935/1518-0557.20170009

Mousavi, S. M., A. Towhidi, M. Zhandi, G. Amoabediny, A. Mohammadi-Sangcheshmeh, M. Sharafi, \& S. M. H. Hussaini. 2019. Comparison of two different antioxidants in a nano lecithin-based extender for bull sperm cryopreservation. Anim. Rep. Sci. 209:1-9. https://doi. org/10.1016/j.anireprosci.2019.106171

Murphy, E. M., B. Eivers, C. M. O. Meara, P. Lonergan, \& Fair. 2017. Effect of increasing equilibration time of diluted bull semen up to $72 \mathrm{~h}$ prior to freezing on sperm quality parameters and calving rate following artificial insemination. Theriogenology 108:217-222. https://doi.org/10.1016/j. theriogenology.2017.11.034

Nugraha, C. D., E. Herwijanti, I. Novianti, A. Furqon, W. A. Septian, W. Busono \& S. Suyadi. 2019. Correlations between age of Bali bull and semen production at National Artificial Insemination Center, Singosari - Indonesia.
J. Indones. Trop. Anim. Agric. 44:258-265. https://doi. org/10.14710/jitaa.44.3.258-265

Nurcholis, R. I. Arifiantini, \& M. Yamin. 2016. Cryopreservation Garut sheep semen using tris egg yolk supplemented omega-3 fish oil salmon. J. Vet. 17:309-315. https://doi. org/10.19087/jveteriner.2016.17.2.309

Nurcholis, S. M. Salamony, D. Muchlis, \& K. I. Prahesti. 2019. System application of artificial insemination technology to the welfare level of cattle breeders in Merauke. IOP Conf. Series: Earth and Environmental Science. 343:1-4. https:// doi.org/10.1088/1755-1315/343/1/012169

Oldenhof, H., M. Gojowsky, S. Wang, S. Henke, C. Yu, K. Rohn, W. F. Wolkers, \& H. Sieme. 2013. Osmotic stress and membrane phase changes during freezing of stallion sperm: mode of action of cryoprotective agents. Biol. Reprod. 88:1-11. https://doi.org/10.1095/biolreprod.112.104661

Ratnani, H., M. N. Ihsan, G. Ciptadi, \& Suyadi. 2017. Effect of $\alpha$-tocopherol supplementation in the extender on the sperm quality of Maduran bull before and after quick freezing. Int. J. Adv. Res. 5:1378-1389. https://doi.org/10.21474/ IJAR01/4849

Sarungallo, Z. L., P. Hariyadi, N. Andarwulan, \& E. H Purnomo. 2015. Characterization of chemical properties, lipid profile, total phenol and tocopherol content of oils extracted from nine clones of red fruit (Pandanus conoideus). K. Journal -Natural Science. 49:237-250.

Sieme, H., H. Oldenhof, \& W.F. Wolkers. 2015. Sperm membrane behaviour during cooling and cryopreservation. Reprod. Dom. Anim. 50:20-26. https://doi.org/10.1111/ rda.12594

Soltan, W. M., E. M. El-Siefy, I. M. Abd El-Razek, \& I. S. ElShamaa. 2016. Efficacy of using soybean milk-based semen extender for freezability of buck spermatozoa. J. Agric. Res. Kafr El-Sheikh Univ. 42:131-143. https://doi. org/10.21608/jsas.2016.3031

Syarifuddin, N. A., A. L. Toleng, D. P. Rahardja, I. Ismartoyo, \& M. Yusuf. 2017. Improving libido and sperm quality of Bali bulls by supplementation of Moringa oleifera leaves. Med. Pet. 40:88-93. https://doi.org/10.5398/medpet.2017.40.2.88

Suyadi, A. Rachmawati, \& N. Iswanto. 2012. Effect of $\alpha$-tocopherol in tris-aminomethane - egg yolk on the semen quality during cold storage in Boer goats .Indonesian Journal of Animal Science. 22:1-8.

Vieira, N., J. D. Losano, D. Angrimani, G. K. V. Kawai, L. Bicudo, B. R. Rui, B. D. C. S. da Silva, M. E. O. D. Assumpção, \& M. Nichi. 2018. Induced sperm oxidative stress in dogs: susceptibility against different reactive oxygen species and protective role of seminal plasma. Theriogenology 108:3945. https://doi.org/10.1016/j.theriogenology.2017.11.020

Wagner, H., J. W. Cheng, \& E. Y. Ko. 2017. Role of reactive oxygen species in male infertility: An updated review of literature. Arab J. Urol. 16:35-43. https://doi.org/10.1016/j. aju.2017.11.001

Yendraliza, Y., T. Tania, R. Misrianti, \& Z. Zumarni. 2019. Livability and recovery rate of Bali cattle spermatozoa during preservation in tris-based egg yolk diluent with different sucrose levels. J. Kedokt. Hewan. 13:55-60. https://doi. org/10.21157/j.ked.hewan.v13i2.13033

Zhang, W., K. Yi, C. Chen, X. Hou, \& X. Zhou. 2012. Application of antioxidants and centrifugation for cryopreservation of boar spermatozoa. Anim. Reprod. Sci. 132:123-128. https:// doi.org/10.1016/j.anireprosci.2012.05.009 